\title{
Confronting the Other/Perceiving the Self
}

\author{
National Historiographies and National Stereotypes in \\ Twentieth-Century Europe
}

Stefan Berger

\begin{abstract}
This contribution deals with the relationship between national historiographies and national stereotypes in twentieth-century Europe. It argues that this relationship was extraordinarily diverse and complex and produced a range of different scenarios. After briefly recalling the role and function of stereotypes and after providing the briefest of introductions to national history writing, it presents five brief case studies. They are, first, the contributions of British and German historians to national stereotyping during the First World War. Secondly, the contribution recalls the stereotyping that followed from the research of so-called Volksgeschichte in Germany during the interwar period. Thirdly, the need to nationalise territories in East-Central and Eastern Europe that had previously not belonged to the nation state gave rise to the formation of new national stereotypes after the end of the Second World War. Fourthly, the hypernationalism of the first half of the twentieth century threw a range of national historical master narratives into a severe crisis after 1945 and created the need to reframe those narratives in the post-Second World War world. The final case study deals with a similar need to recast national historical master narratives after the end of the Cold War from the 199 os onwards.
\end{abstract}

\section{Introduction}

Standing on Gianicolo Hill overlooking Rome one is confronted with the monument to Giuseppe Garibaldi, unveiled in 1895. Garibaldi was, of course, one of the central heroes of the Risorgimento - an archetypal romantic figure fighting the cause of national unity and liberty not just in Italy but also in Latin America. He sits alongside a whole range of other romantic liberators of allegedly unfinished or repressed nations in the pantheon of nineteenth-century national movements. The nation states they were striving for and that, in many cases, were eventually to emerge from history took great care to present their heroes,

(C) STEFAN BERGER, 2021 | DOI:10.1163/9789004436107_003

This is an open access chapter distributed under the terms of the CC BY-NC-ND 4.0 license. 


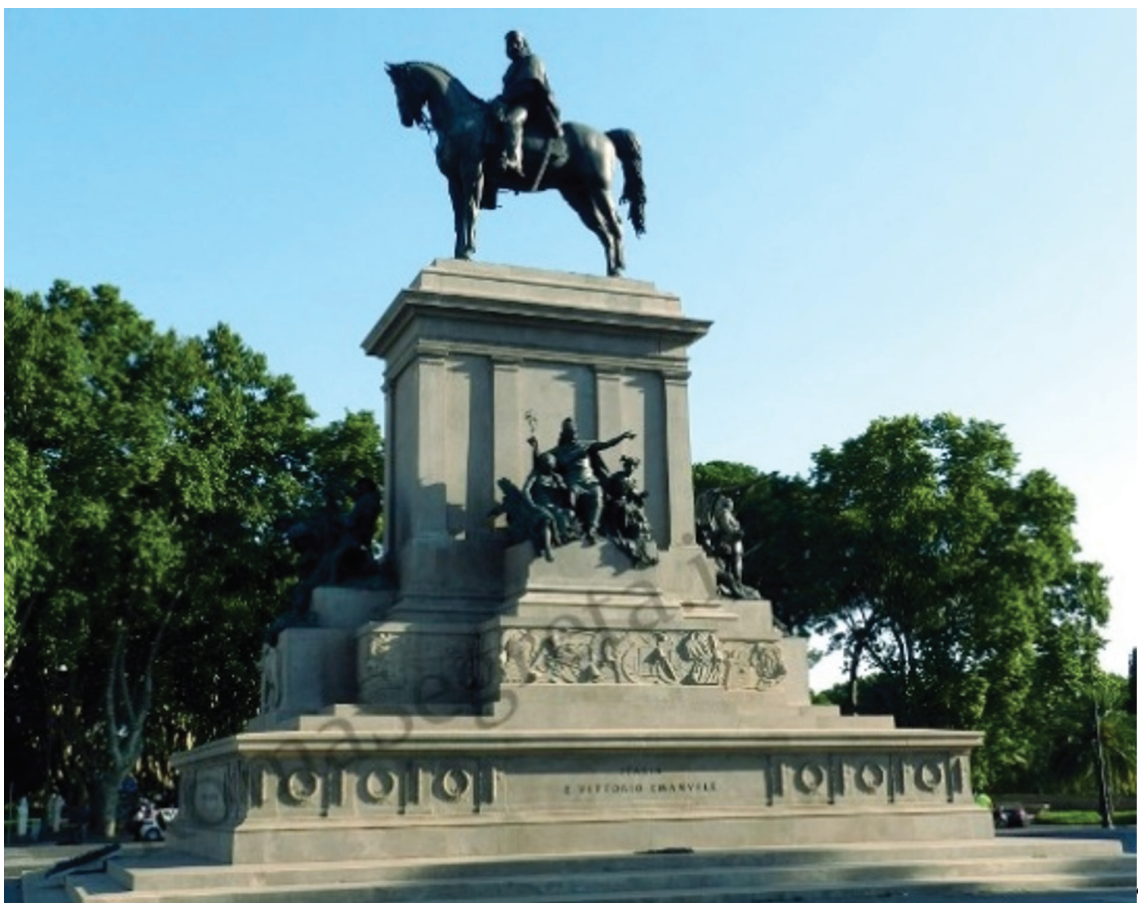

FIGURE 1.1 Statue of Garibaldi on the Gianicolo hill in Rome

their heroism and the heroic times they shaped in the best of lights in their museums, their monuments and their history books. This is certainly true for Garibaldi: the incredibly tall statue of Garibaldi on horseback on the Gianicolo depicts a victor - majestic and glorious, a true father of the nation. It recalls all the myths of the Risorgimento on which the official Italy thrived after its unification, even if it, by and large, ultimately failed to 'make Italians', at least before the First World War. ${ }^{1}$ Perhaps because the Italian national elites were struggling hard to 'make Italians', they were particularly wary of protecting their national myths and the stereotypical representation of historical events they entailed. Professional historians and historical writing were sometimes seen as a threat to those "beautiful legends", as they were called by Giovanni Giolitti who closed the archives of the Risorgimento because he did not want historians to destroy those myths. ${ }^{2}$

This may seem an extreme case of an adverse relationship between national historiographies and national stereotypes in twentieth-century Europe, and in

1 Massimo d'Azeglio, another pioneer of Italian unification is credited with saying: "We have made Italy. Now we have to make Italians." See Hom (2013).

2 Cited in Laven (2006), p. 270. 
fact, as I shall argue in this article, this relationship was extraordinarily diverse and complex and produced a range of different scenarios. After briefly recalling the role and function of stereotypes and after providing the briefest of introductions to national history writing, I will present five case studies in which the relationship between national stereotyping and perceptions of national history are particularly acute. They are, first, the contributions of British and German historians to national stereotyping during the First World War. Secondly, I will recall the stereotyping that followed from the research of so-called Volksgeschichte in Germany during the interwar period. Thirdly, the need to nationalise territories in East-Central and Eastern Europe that had previously not belonged to the nation state gave rise to the formation of new national stereotypes after the end of the Second World War. Fourthly, the hypernationalism of the first half of the twentieth century threw a range of national historical master narratives into a severe crisis after 1945 and created the need to reframe those narratives in the post-Second World War world - with the help of several stereotypical images. My final case study will deal with a similar need to recast national historical master narratives after the end of the Cold War from the 199os onwards. I will conclude with some remarks on the relationship between national stereotyping and national history writing.

\section{Some Preliminary Thoughts on Stereotypes and on National Histories}

Katy Greenland has defined stereotypes as "probabilistic, generalised representations of any social group". ${ }^{3}$ They play an important role in social cognition, as they allow people to categorize and thereby simplify the world around them. Their effects on perception, thought and behaviour is considerable. Bias and prejudice are an integral part of stereotyping leading to the frequent denigration of 'others'. The more social groups suffer from anxiety about other groups, the more they will practice negative stereotyping. These stereotypes are often highly abstract, which helps to make their cores more durable, as they are very difficult to destabilise with specific counter-examples. At the level of abstraction at which stereotypes operate, specific examples can always be dismissed as the exception to the rule.

A close analysis of national histories leads to the conclusion that they are often characterised by positive auto-stereotypes and negative stereotypes

3 Greenland (2000), p. 15 . 
about 'others', which can be both external and internal. ${ }^{4}$ Stereotypical ideas of 'the other' are due to deep insecurities about national identity. As Peter Fritzsche has argued:

The relationship between victimhood and violence is embedded in most national historiographies [...]. [The national idea, S.B.] is first conjured up as being under threat. And it is this state of alarm that produces the energy to override competing identities, often violently. Violence is inscribed in the national narrative because the nation imagines itself first and foremost as a collective good that is incomplete and imperilled. In many ways, the national narrative must sustain itself by reproducing its own state of jeopardy. National histories tremble as a result. ${ }^{5}$

To take the example of Germany after unification of 1871 , here national histories contributed to constructing a whole string of internal and external enemies in order to strengthen an altogether insecure national 'we' group that could not even produce a majority for unification in the first all-German parliament. Hence the Catholics and the Socialists were picked upon as two groups whose primary loyalty did not lie with the German fatherland, but rather with the Pope in Rome and with international socialism respectively. They were denounced as 'fellows without a fatherland' and the national 'we' group could define itself more strongly against those 'out' groups. Alongside the internal enemies, German nationalism after 1871 had many external enemies, especially the so-called 'hereditary enemy ' of France, regarded as a country that wanted to weaken, dismember and humiliate Germany for many centuries. Britain was stereotyped as 'perfidious Albion' that was double-faced and could not be trusted. Its economistic mentality only looked for profit and was allegedly unable to produce any true culture (Kultur). Russia and many of the East European peoples were denounced as Slavs, who allegedly were culturally much inferior to the Germans and whose civilisation depended partly on medieval German colonisation eastwards. Again, the external enemies also served the purpose of re-assuring an insecure German 'we' against its immediate surroundings. ${ }^{6}$

4 This observation is based on the European Science Foundation project about the writing of national histories in modern Europe which ran between 2003 and 2008 and involved more than 25 o scholars from 29 European countries. It was the basis for a nine-volume 'Writing the Nation' series with Palgrave MacMillan, the last volume of which attempts a synthesis. See Berger with Conrad (2015).

5 Peter Fritzsche, 'National Narrative and Untimely Death', keynote address to the final conference of the NHIST programme, Manchester, 23-25 October 2008.

6 This is discussed at length in Berger (2005a), chap. 4. 
Historiography contributed significantly to re-enforcing such stereotypes, as history was one of the most important ingredients in shaping national master narratives. Despite the victory of 'scientificity' in nineteenth-century historical writing, ${ }^{7}$ historiographical nationalism was at its strongest arguably in the century between the 185 os and the 1950s. When history became a Wissenschaft, it drew the lines more firmly to other disciplines, and, above all, to 'amateur' historical writing. The professionalisation and institutionalisation of historical writing, often state-driven, was accompanied by an exclusion of 'the amateur'. It was now a particular method and long years of university study, in which this method was acquired, and then long years of apprenticeship as a professional historian in the archives and libraries ultimately 'made' the historian. ${ }^{8}$ Only where such state-driven professionalisation processes were weak, such as in Britain, did amateurs continue to play a bigger role in the history business. ${ }^{9}$ Ultimately, however, professional historians everywhere claimed (very successfully overall) that they were the only ones who could speak authoritatively about the past, but this claim did not prevent them from strong political commitments, including a strong nationalist activism, both on behalf of nation states and on behalf of national movements seeking to create a nation-state. ${ }^{10}$ Their scientificity went hand in hand with historiographical nationalism and was often strongly influenced by stereotypes of self and others. Historians did not prove immune to the general cognition processes of stereotyping.

In fact I would like to use the following five case studies to demonstrate that academic national history writing could and did transport national stereotypes more often than it questioned and destroyed them. It could do both, of course, but there are famous examples of the dangers of destroying those stereotypes dangers to the historians' career and sometimes life. Take the example of the young Gyula Szekfü in Hungary who was in the middle of the so-called Rákóczi controversy of 1913. Szekfü had published a book that demolished the national hero Francis II. Rákóczi and presented him as a rejected and bitter politician who, towards the end of his life, recognised his own failures. This interpretation was itself driven by the political sentiments of Szekfü, who was pro-Habsburg at the time. Yet the Hungarian nationalists criticised this interpretation viciously and almost destroyed the promising young career of the historian who would later become one of the most distinguished among his profession in Hungary. ${ }^{11}$

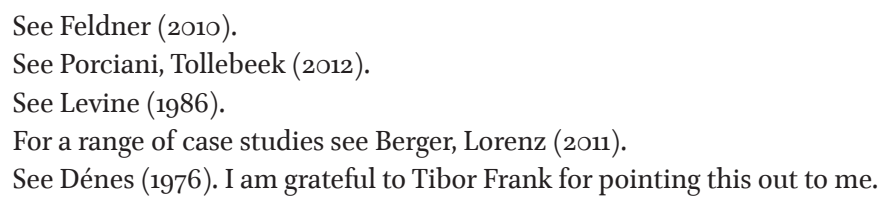


Or take the example of the German historian Emil Ludwig, who did not have a university position, but was so successful in his writing of political biography that he could live extremely well as an independent author in the Weimar Republic. Amongst those biographies were strongly critical ones of Bismarck and of Wilhelm II. Especially the former was still a revered hero among most Germans, including most professional historians. The vitriolic attacks on Ludwig were unceasing and the National Socialists were to burn his books. By that time, however, he had already withdrawn to exile in Switzerland. ${ }^{12}$ As the cases of Szekfü and Ludwig demonstrate, it was easier to live with, condone and even promote stereotypes. As the following five case studies seek to demonstrate, this is precisely what they did, especially when they felt called upon to defend their respective nation states against others.

\section{3 \\ Historians as Purveyors of Stereotypes in Twentieth-Century Historiography}

Our first case study relates to the historians' agency in and around the First World War. British historians before 1914 were divided between those holding pro-German and those holding anti-German sentiments. Their positions were often based on stereotypes of what was the essence of the German nation: whereas the pro-German camp argued that the German Mensch was modern, progressive and educated (gebildet), the anti-German camp held that the German was born with a Pickelhaube and was inherently militarist, aggressive and authoritarian. These traits were then often historicised, i.e. history became an argument to bolster particular stereotypes of Germany. At the outbreak of the First World War, many pro-German historians were hugely disappointed as their particular vision of what 'the German' was, seemed to be drowned out by their opponents' vision of 'the Hun'. British historians during the First World War repeatedly came out with stereotypical accusations of Prussianism and posited Prussian militarism against English liberty, i.e. they juxtaposed a negative stereotype of the other with a positive auto-stereotype. ${ }^{13}$ A particularly interesting and after 1918 influential position was taken by William Harbutt Dawson. Like many of his fellow pro-German historians he was deeply shocked by the nationalist pro-war sentiments in Germany, and he came up with an ingenious solution to the problem, i.e. the theory of the two Germanies. A

\footnotetext{
12 See Ullrich (2005).

13 See Wallace (1988).
} 
long-standing divide had been going through Germany pitting the south against the north and the Rhineland against Prussia. Whereas Prussia and the North, Dawson conceded, had aggressive, militarist and antiliberal traits, the south was progressive, modern and the harbinger of a universalist humanistic ideal of Bildung. ${ }^{14}$ Such stereotypes became the intellectual justification for a new positive perception of Weimar Germany: the positive Germany had allegedly defeated its negative other and now needed the support and friendship of Britain again.

If we look at German historiography, it was strongly engulfed in the outbreak of hyper-nationalism at the beginning of the war, which engulfed almost all of the intellectuals in Germany. ${ }^{15}$ They again worked strongly with stereotypes, contrasting German discipline and Kultur with Western shallowness, Slav barbarity and French decadence. All of the tropes that were used in this negative stereotyping of the 'enemy' in the war had already been well established before 1914. It was easy to fall back on them in war-time. Thus, for example, Gerhard von Schulze Gaevernitz, an economist well known also for his historical work, among other topics on the British historian and writer Thomas Carlyle, argued in 1915: "The Anglo-Saxon, in his highest form, is a man as hard as steel and of the toughest constitution, kalt wie Hundeschnauze, completely lacking in artistic temperament, the type who aims to subordinate beauty and colour to brutal numbers [...]."16 Endless other examples could be cited. Friedrich Meinecke published a book justifying the German declaration of war and using crude stereotypes to contrast an allegedly higher German form of humanity with the humanity of the West which he identified with uniformity, egotism and degeneracy. ${ }^{17}$ Overall, most German historians backed the war effort right up to the end, and it is no surprise that many of them even peddled the 'stab-in-theback' myth after 1918 and supported an authoritarian redirection of German politics away from Weimar and its liberal foundations.

With our second example we stay with German historiography, as it saw the rise of so-called Volksgeschichte as a direct result of the lost war in the interwar period. Volksgeschichte was many things, but it essentially amounted to a racialisation and biologisation of history writing. ${ }^{18}$ The strong state-orientation of German historiography before 1914 was no longer seen as being sufficient to underpin a powerful sense of German national identity. Hence many younger

\footnotetext{
14 See Berger (2001).

15 See Von Ungern-Sternberg von Pürkel, von Ungern-Sternberg (1996)

16 Cited in Stibbe (2003), p. 249. See also, more generally, Stibbe (2001).

17 See Meinecke (1915).

18 See Oberkrome (1993); Lambert (1995); Schöttler (1997); Schulze, Oexle (200o).
} 
historians turned to the people, the Volk, but not in a democratic political sense. Instead they constructed it in a racial, biological sense. In their attachment to historiographical nationalism, proponents of Volksgeschichte stood on the same platform as their often older colleagues still attached to statism. Both camps lend their pens to the service of a revision of the Versailles Treaty in the interwar period. ${ }^{19}$ Race was undoubtedly a far more identitarian category than state, and the racial ideal, upheld by Volksgeschichte, incorporated a whole host of stereotypical ideas of self and other. Thus, there was, for example, the centuries-old idea of the 'civilising mission' of the Germans in the East which was strongly related to the stereotype of the Slavs as not being capable of producing civilisation. This gave rise within Volksgeschichte to ideas about German 'cultural territory' (Kulturboden): numerous German historians, including the young Werner Conze, began writing histories of the German settlements in the East hoping to deliver the proof of German cultural and often racial superiority vis-à-vis the Slav population in Eastern Europe. From there it was but a small step to German historians contributing to the infamous Generalplan Ost in the Second World War, which foresaw vast population moves and the settlement of Germans in Europe's east, with the Slav population playing the role of de facto slaves to the German master race. ${ }^{20}$ Ostforschung used stereotypes to justify the cultural-racial expansion of Germans eastwards, but it was paralleled by Westforschung, which sought to justify the annexation of parts of the Low Countries into a greater Germany during the Second World War. Here, just as in Ostforschung, stereotypes played an influential role in structuring research agendas and underpinning historical analysis. Thus, Wolfgang Petri referred to common linguistic, cultural and ethnic characteristics of the Dutch and the Germans using well-known stereotypes about national character to bolster his historical interpretations. ${ }^{21}$

Our third case study looks at the recasting of national historical master narratives in many European nation states at the end of the Second World War. ${ }^{22}$ Stereotypes were once again crucial in allowing those narratives, many of which had been damaged in and by the war, to be revived after 1945. If we start with Germany, the defeated country had to reject almost everything that the National Socialists had stood for. The anti-fascism of the Communist German Democratic Republic (GDR) legitimated itself in total contradistinction to National Socialist rule. Yet underneath the anti-fascist gloss, sometimes

\footnotetext{
19 See Harvey (2003), chap. 6.

20 See Heim, Aly (1991); Schönwalder (1992); Haar, Fahlbusch (2005).

21 See Dietz, Gabel, Tiedau (2003).

22 See Berger $(2005 \mathrm{~b})$.
} 
very traditional notions of German history and stereotypical perceptions of Germanness continued in the GDR and were bolstered by its Marxist-Leninist historiography. ${ }^{23}$ All over Eastern Europe, the national histories together with the national stereotypes on which they rested were simply painted red, but they remained essentially unchanged beneath this coat of red paint, which over time, in many countries, showed severe signs of deterioration, making the older nationalist narratives and stereotypes re-appear from underneath. Stereotypical ideas about national peculiarity and heroic ideas of the nation were thus strongly coming back to the surface after the collapse of communism from the late 1980 on onwards. ${ }^{24}$

In the capitalist Federal Republic of Germany (FRG) there was one very important ideological bridge that allowed many supporters of Nazism to cross over into the post-war camp of 'the West' and that ideological bridge was anti-Communism. From the perspective of many in the early FRG, if the National Socialists had been wrong about almost everything, they had been right in their anti-Communism. The Cold War confirmed this, and West German historians could use ideas around the Asianness of Russia and the Soviet Union to posit it as a negative other to the idea of the occident (Abendland) that became popular again with some West German historians in the late 1940 and 1950s. A good Germany, connected, above all, to the conservative military resistance to National Socialism associated with 20 July 1944 (almost all of those conservative military officers had excellent anti-Communist credentials), could be constructed against a stereotypical other - the one-dimensional communist who, through the theory of totalitarianism, was connected to the ultimate evil, National Socialism. Christianity, antiquity and humanism were seen as the defining features of Europe, and the Soviet Union and much of Eastern Europe were decidedly not part of it. Democratic anti-Communism merged with traditional anti-Slav and anti-Russian prejudices, and, in countries such as the FRG, some historians harked back to older stereotypical ideas about German superiority vis-à-vis Eastern Europe. ${ }^{25}$

If we turn to Britain we find that some of the most traditional stereotypes about its national history are retained and recast in the post-war period. The existing liberal historical master narrative depicting Britain as the land of liberty, freedom and constitutionalism, the mother of parliaments and progressive, evolutionary change was adapted by left-of-centre historians who

\footnotetext{
23 See Iggers (1989).

24 See Antohi, Trencsényim, Apor (2008).

25 See Schulze (1989), pp. 211f., 266ff. For Schnabel's history writing more generally see Hertfelder (1998).
} 
extended these stereotypical definitions of Britishness to 'the people.'.6 Out of the 'people's war' emerged a 'people's history' that sought to extend British democracy and end its exclusivity in terms of class. The victory of the Labour Party in 1945 made it possible to build the 'homes fit for heroes' that had already been promised at the end of the First World War. The Labour government started a new municipal housing scheme that was to create cheap and affordable housing for many of its working-class voters. It also institutionalised a revolutionary health service system for all citizens in the form of the National Health Service (NHS). The historians, or some of them, especially members of the Communist Party's Historians Group, ${ }^{27}$ delivered the historical national master narratives that went with this political change, and they did so by adapting Britain's very traditional national master narrative, often referred to as Whig history. It now got a little reddish coat to signal an inclusive rather than an exclusive Britain.

In post-war Italy, we find a very similar attempt to adapt what had been the dominant national historical master narrative to the situation after 1945 . Ever since the second half of the nineteenth century the 'beautiful myths' of the Risorgimento had been the basis of Italian constructions of national identity. Fascism had also presented itself as the true inheritor of the Risorgimento as had anti-fascists, e.g. the brothers Roselli. ${ }^{28}$ In post-war Italy the Risorgimento was re-loaded once more. The resistance now inherited the mantle of the Risorgimento and became the key to continuing with positive national histories rooted in stereotypical depictions of the era of Italian unification. ${ }^{29}$

While we can find the retention of traditional stereotypes in the recasting of national historical master narratives after 1945 in large parts of Europe, we can identify no such re-orientation on the Iberian peninsula, as the authoritarian right-wing dictatorships survived the end of fascism in Europe, despite the fact that they had strongly sympathised with fascism in the 1930s and 1940s. Here the occidentalist, Catholic, and familial stereotypes were still shaping the authoritarian historical narratives emanating from those countries until the 1980 s. $^{30}$

Our fifth and final case study considers the renationalisation of historical master narratives after the end of Communism. In post-Communist states we can observe that national historians harked back to positive auto-stereotypes and negative othering - a story all-too familiar from the interwar period. Strong anti-Communism found expression in public history ventures such as

\footnotetext{
$26 \quad$ See Berger (2014).

27 See Kaye (1984); Schwartz (1982); Elliott, Hobsbawm (2010).

28 See Morgan (1999).

29 See Battente (2000/2001).

$30 \quad$ See Seixas (1993).
} 
Budapest's House of Terror museum. ${ }^{31}$ Here the stereotypical Communist villain is typically not Hungarian but a foreigner. In the terribly divided historical culture of Ukraine, traditional stereotypes also to this very day and especially in the political crisis of recent years served the purpose of marking the respective 'other': the 'Asian' Russian and the Ukranian as Western dupe. ${ }^{32}$ Excluding Russians as Asians from the polity has also been a standard trope in many of the Baltic states. Estonian historians have been prominent in the Estonian revolution of the late 1980s and early 199os resurrecting ideas of national history and heritage from the interwar period. ${ }^{33}$ This went alongside the rediscovery of right-wing political leaders of the interwar period who have been re-inserted into the historical pantheons. This is true for István Tisa in Hungary, ${ }^{34}$ as well as for the anti-Semite Symon Petljura in the Ukraine. ${ }^{35}$ The Polish museum wars that have been raging for around two decades also testify to the impact of stereotypes on the master narrative of a Catholic, nationalist and traditionalist Poland.

The growth of stereotypical images in historical master narratives cannot only be observed in post-Communist East European societies. It is equally true for separatist movements from western multinational states such as Scotland in the UK or Catalonia in Spain, or, indeed, Flanders in Belgium. The civic leftwing nationalism in Scotland often prides itself in being primarily political, but it nevertheless constantly appeals to and mobilises the cultural heritage and the cultural roots of Scotland. A collection on Scottish history from 1992, aimed not just at an academic audience, starts: "Scotland's history is important. It gives us as individuals and as members of Scottish society a vital sense of where we are and how we got here." 36 The Catalan National History Museum in Barcelona is full of positive auto-stereotypes about the country and its people, whilst the rest of Spain is the absent 'other' in the museum. The Flemish nationalists around Bart de Wever, himself a trained historian, are championing an autonomous history of Flanders building on all the stereotypical Flemish myths, whilst Henri Pirenne's vision of a Belgium as a bridge between the Romanesque and Germanic cultures has long been out of print in Belgium. ${ }^{37}$

\footnotetext{
31 See Apor (2010).

32 See Kuzio (2005).

33 See Must (2010).

34 See Trencsényi, Apor (2008), p. 45.

35 In May 2008, on a visit to the Ukranian national history museum in Kiev, the author was surprised to see such a positive depiction of Petljura.

$36 \quad$ Donnachie, Whatley (1992), p. 1.

37 I am grateful to Jo Tollebeek for pointing this out to me.
} 
In recasting a wide variety of national histories after the end of the Cold War, stereotypes have often been used to depict an idealised norm, against which the national history is then measured. Take, for example, Germany's 'search for normality' after reunification in 1990. ${ }^{38}$ Heinrich August Winkler's attempt to provide the country with a new master narrative that is measured against the normative ideal of 'the 'West' is a good example of this tendency. ${ }^{39}$ And conservative British historians have worked for some time to prepare the country for Brexit. Thus David Starkey, in his 2001 Medlicott lecture, already lamented a loss of identity and history inside the European Union: "maybe we have a future as a series of disparate regions of the European Union [...]. But where a history - where an English history fits in [...] a sense of England as a place that once existed, that once mattered, that once was glorious - I'm really not sure."40 The Brexit camp relied heavily in its campaign on positive auto-stereotypes regarding Britain and 'its' Commonwealth. Britain allegedly fought alone in the Second World War. Its dead, soldiers and civilians, it was often argued, did not die for Britain being subsumed in a European Union allegedly dominated by Germany. This type of argument strongly appealed to a very traditional negative stereotype of the German 'other' in post-Second World War Britain.

\section{4}

\section{Conclusion}

Scientific history can break stereotypes and it can rely on stereotypes. The susceptibility of historians to stereotypes is certainly crucial to the myth-making aspects of national histories that have been at the centre of attention in this article. As the above case studies have sought to demonstrate, time and again, throughout the twentieth century, national historians used narrative frames that were deeply indebted to stereotypes. The binary construction of positive auto-images with negative images of the 'other' contributed to the construction of national historical master narratives that owed much to stereotypes. If national histories have been an important part of constructions of national character, then stereotypes have been an essential ingredient of notions of national character. We have observed above that stereotypical images of the 'other' were most strongly mobilised at times of conflict, including wars, incidents of ethnic cleansing and post-war reconstruction periods.

\footnotetext{
$38 \quad$ See Berger (2003).

39 See Berger (2010b).

40 See Starkey (2001).
} 
The above reflections are rather essayistic and impressionist, but if they are correct in assuming an important impact of stereotypes on grand historical narratives of nation, we need to examine this much more systematically. As Mark Knights has stated:

History and social psychology share interests in the social sphere, the arts of persuasion and the formation of attitudes. As a result, both disciplines are interested in the construction, manipulation, dissemination and evolution of stereotypes and the prejudices on which they feed. ${ }^{41}$

We thus would need to examine the language of the historian with the tools from social psychology in order to arrive at a better understanding of how and with what purpose those stereotypes are manipulated and disseminated, and how they have evolved over time. Those teaching rhetoric in ancient Greece and Rome had already been well aware of the usefulness of negative stereotyping to put down an adversary. It is about time for the history of historiography to buckle down and examine historical narrative closely to find out about the subtle and not-so-subtle use of stereotypes in historical writing.

\section{Bibliography}

Antohi, Sorin, Balázs Trencsényi, Péter Apor (eds) (2008).Narratives Unbound. Historical Studies in Post-Communist Eastern Europe (Budapest: Central European University). Apor, Peter (2010). 'Eurocommunism. Commemorating Communism in Contemporary Eastern Europe', in Małgorzata Pakier, Bo Stråth (eds), A European Memory? Contested Histories and Politics of Remembrance (Oxford: Berghahn), pp. 233-246.

Battente, Saverio (2000/2001). 'Nation and State Building in Italy. Recent Historiographical Interpretations', Journal of Modern Italian Studies 5, pp. 310-321 and 6, pp. 94-105.

Berger, Stefan (2001). 'William Harbutt Dawson and Germany in the Interwar Period', English Historical Review 116.1, pp. 76-112.

Berger, Stefan (2003). The Search for Normality. National Identity and Historical Consciousness in Germany since 180o, 2nd edn (Oxford: Berghahn).

Berger, Stefan (2005a). Germany. Inventing the Nation (London: Edward Arnold).

Berger, Stefan (2005b). 'A Return to the National Paradigm? National History Writing in Germany, Italy, France and Britain from 1945 to the Present', Journal of Modern History 77.3, pp. 629-678. 
Berger, Stefan (2010). 'Rising Like a Phoenix. The Renaissance of National History Writing in Britain and Germany since the 1980s', in Stefan Berger, Chris Lorenz (eds), Nationalizing the Past. Historians as Nation-Builders in Modern Europe (Basingstoke: Palgrave MacMillan), pp. 426-451.

Berger, Stefan (2014). 'From the English isles to the history of four nations. National history writing in Britain in comparative perspective' in Joseba Agirreazkuenaga Zigorraga, Eduardo J. Alonso Olea (eds). Estatu-nazioen baitako nazioak. Naziogintza kulturala eta politikoa, gaur egungo europan (Bilboa: Editorial Base), pp. 11-26.

Berger, Stefan, Chris Lorenz (eds) (2010). Nationalizing the Past. Historians as NationBuilders in Modern Europe (Basingstoke: Palgrave MacMillan).

Berger, Stefan with Christoph Conrad (2015). The Past as History. National Identity and Historical Consciousness in Modern Europe (Basingstoke: Palgrave MacMilllan).

Dénes, Iván Zoltán (1976). A „realitás” illúziója. A historikus Szekfü Gyula pályafordulója (Budapest: Akadémiai Kiadó).

Dietz, Burkhard, Helmut Gabel, Ulrich Tiedau (eds) (2003). Griff nach dem Westen. Die 'Westforschung' der völkisch-nationalen Wissenschaften zum nordwesteuropäischen Raum, 1919-1960 (Münster: Waxmann).

Donnachie, Ian, Christopher Whatley (1992). 'Introduction', in Ian Donnachie, Christopher Whatley (eds), The Manufacture of Scottish History (Edinburgh: Polygon).

Elliott, Gregory, Eric Hobsbawm (2010). History and Politics (London: Pluto Press).

Feldner, Heiko (2010). 'The New Scientificity in Historical Writing around 180o', in Stefan Berger, Heiko Feldner, Kevin Passmore (eds), Writing History. Theory and Practice, 2nd edn (London: Bloomsbury), pp. 3-21.

Greenland, Katy (200o). “Cant' Live With Them, Can't Live Without Them”. Stereotypes in International Relations', in Rainer Emig (ed.), Stereotypes in Contemporary Anglo-German Relations (Basingstoke: Palgrave MacMillan), pp. 15-30.

Haar, Ingo, Michael Fahlbusch (eds), German Scholars and Ethnic Cleansing 1919-1945 (Oxford, New York: Berghahn 2005).

Harvey, John L. (2003). The Common Adventure of Mankind. Academic Internationalism and Western Historical Practice from Versailles to Potsdam, Ph.D. Thesis Pennsylvania State University.

Heim, Susanne, Götz Aly (1991). Vordenker der Vernichtung. Auschwitz und die deutschen Pläne für eine neue europäische Ordnung (Hamburg: Hoffmann \& Campe).

Hertfelder, Thomas (1998). Franz Schnabel und die deutsche Geschichtswissenschaft. Geschichtsschreibung zwischen Historismus und Kulturkritik (Göttingen: Vandenhoeck \& Ruprecht).

Hom, Stephania Malia (2013). 'On the Origins of Making Italy. Massimo d'Azeglio and "Fatta L'Italia, Bisogna Fare gli Italiani”, Italian Culture 31.1, pp. 1-16.

Iggers, Georg G. (1989). 'New Directions in Historical Studies in the German Democratic Republic', History and Theory 28, pp. 59-77. 
Kaye, Harvey J. (1984). British Marxist Historians. An Introductory Analysis (Cambridge: Polity Press).

Knights, Mark (2014). 'Historical Stereotypes and Histories of Stereotypes', in Cristian Tileaga, Jovan Byford (eds), Psychology and History. Interdisciplinary Perspectives (Cambridge: Cambridge University Press), pp. 242-267.

Kuzio, Taras (2005). 'Nation Building, History Writing and Competition over the Legacy of Kyiv Rus in Ukraine', in Nationalities Papers 33.1, pp. 29-58.

Lambert, Peter (1995). 'German Historians and Nazi Ideology. The Parameters of the Volksgemeinschaft and the Problem of Historical Legitimation, 1930-1945', European History Quarterly 25, pp. 555-582.

Laven, David (2006). 'Italy', in Timothy Baycroft, Mark Hewitson (eds), What is a Nation? Europe 1789-1914 (Oxford: Oxford University Press), pp. 255-271.

Levine, Philippa (1986). The Amateur and the Professional. Antiquarians, Historians and Archaeologists in Victorian England 1838-1886 (Cambridge: Cambridge University Press).

Morgan, Philip (1999). 'Reclaiming Italy? Antifascist Historians and History in "Justice and Liberty"', in Stefan Berger, Mark Donovan, Kevin Passmore (eds), Writing National Histories. Western Europe since 1800 (London, New York: Routledge), pp. 150-16o.

Meinecke, Friedrich (1915). Die deutsche Erhebung von 1914. Vorträge und Aufsätze (Stuttgart: J. G. Cotta).

Must, Aadu (2010). 'Estonia', in: Ilaria Porciani, Lutz Raphael (eds), Atlas of European Historiography. The Making of a Profession 1800-2005 (Basingstoke: Palgrave MacMillan), p. 80-81.

Oberkrome, Willi (1993). Volksgeschichte. Methodische Innovation und völkische Ideologisierung in der deutschen Geschichtswissenschaft, 1918-1945 (Göttingen, Vandenhoeck \& Ruprecht).

Porciani, Ilaria, Jo Tollebeek (eds) (2015), Setting the Standards. Institutions, Networks and Communities of National Historiography (Basingstoke: Palgrave MacMillan).

Schönwälder, Karen (2002). Historiker und Politik. Geschichtswissenschaft im Nationalsozialismus (Frankfurt a.M.: Campus).

Schöttler, Peter (ed.) (1997). Geschichtsschreibung als Legitimationswissenschaft 1918-1945 (Frankfurt a.M.: suhrkamp).

Schulze, Winfried (1989). Deutsche Geschichtswissenschaft nach 1945, (Munich: Oldenbourg).

Schulze, Winfried, Otto Gerhard Oexle (eds) (2000), Deutsche Historiker im Nationalsozialismus (Frankfurt a.M.: Fischer).

Schwartz, Bill (1982). "The People" in History. The Communist Party Historians' Group, 1945-1956', in Richard Johnson et. al. (eds), Making Histories. Studies in HistoryWriting and Politics (London: Hutchinson), pp. 44-95. 
Seixas, Xose M. Nunez (1993). Historiographical Approaches to Nationalism in Spain (Saarbrücken: Verlag Breitenbach).

Starkey, David (2001). 'The English Historians' Role and the Place of History in English National Life', The Historian 71, pp. 6-15.

Stibbe, Matthew (2001). German Anglophobia and the Great War, 1914-1918 (Cambridge: Cambridge University Press).

Stibbe, Matthew (2003) 'German Historians' View of England in the First World War', in Stefan Berger, Peter Lambert, Peter Schumann (eds), Historikerdialoge. Geschichte, Mythos und Gedächtnis im deutsch-britischen kulturellen Austausch 1750-2000 (Göttingen: Vandenhoek \& Ruprecht).

Trencsényi, Balázs, Péter Apor (2008). 'Fine-Tuning the Polyphonic Past. Hungarian Historical Writing in the 199os', in Sorin Antohi, Balázs Trencsényi, Péter Apor (eds), Narratives Unbound. Historical Studies in Post-Communist Eastern Europe (Budapest: Central European University), pp. 1-10o.

Ullrich, Sebastian (2005). "'Der Fesselndste unter den Biographen ist heute nicht der Historiker". Emil Ludwig und seine historischen Biographien', in Wolfgang Hardtwig, Erhard Schütz, Wolfgang Becker (eds), Geschichte für Leser. Populäre Geschichtsschreibung in Deutschland im 20. Jahrhundert (Stuttgart: Steiner), pp. 35-56.

Von Ungern-Sternberg von Pürkel, Jürgen, Wolfgang von Ungern-Sternberg (1996). Der Aufruf an die Kulturwelt. Das Manifest der 93 und die Anfänge der Kriegspropaganda im ersten Weltkrieg (Stuttgart: Steiner).

Wallace, Stuart (1988). War and the Image of Germany. British Academics, 1914-1918 (Edinburgh: John Donald). 